\title{
Mesenchymal stem cell therapy in acute kidney injury (AKI): review and perspectives
}

\author{
DChristian Sávio-Silva ${ }^{1}$ \\ Poliana Evelyn Soinski-Sousa ${ }^{1}$ \\ (iD) Maria Theresa A Balby-Rocha' \\ (iD) Ádyna de Oliveira Lira ${ }^{1}$ \\ (iD) Érika Bevilaqua Range/1,2
}

1. Hospital Israelita Albert Einstein, São Paulo, SP, Brasil 2. Universidade Federal de São Paulo - Escola Paulista de Medicina, São Paulo, SP, Brasil

http://dx.doi.org/10.1590/1806-9282.66.S1.45

\section{SUMMARY}

INTRODUCTION: Acute kidney injury (AKI) is highly prevalent today. It has a multifactorial aetiology and affects people of all ages, genders and ethnicities. Its treatment is essentially supportive of renal function substitution, so new treatment alternatives such as mesenchymal stem cell therapy (MSCS) should be investigated.

METHODS: This review encompasses our understanding of the main mechanisms of action of MSCs in preclinical models of AKI by renal pedicle clamping ischemia-reperfusion, chemotherapy (cisplatin) and kidney transplantation in small and large animals, as well as outcomes in patients with AKI due to ischemia and kidney transplantation.

RESULTS: Cellular therapy with MSCs has benefits in preclinical studies of AKI through various mechanisms, such as anti-inflammatory, antiapoptotic, oxidative anti-stress, antifibrotic, immunomodulatory and proangiogenic. In humans, MSC therapy is safe and effective. However, the challenges of MSC cell therapy include investigating protocols about the optimal dose of these cells, the route and frequency of appropriate administration, and the design of further biodistribution studies over a long follow-up period. In addition, a better understanding of molecular signalling and cellular interactions in the microenvironment of each organ and tissue is needed in order to define the best time to administer MSCs. Another challenge would be to mitigate the heterogeneity of the profile of cultured MSCs through preconditioning approaches.

CONCLUSIONS: Cellular therapy with MSCS is very promising and should be part of the treatment of AKI patients in combination with other approaches already available, helping to accelerate recovery and/or slow the progression to chronic kidney disease. Randomized, multicentre controlled studies are needed to develop robust protocols that validate population-based cell therapy with MSCs.

KEYWORDS: Acute kidney injury. Cell therapy. Outcomes. Clinical trials.

\section{INTRODUCTION}

In the current review, we will be addressing the challenges of mesenchymal stem cell therapy (MSCs), as these cells are already being tested in human clinical studies.

\section{MESENCHYMAL STEM CELLS (MSCS)}

MSCs, also known as stromal stem cells, are a diverse cell population with a wide range of potential therapeutic applications for different organs and tissues. MSCs can be derived from many tissue 
sources consistent with their possibly ubiquitous distribution.

These cells are characterized by clonogenicity, self-renewal, differentiation in different lineages and by regenerating organs with certain lesions. The International Society for Cellular Therapy has proposed a series of criteria for defining human MSCs (H-MSCs), namely: (1) adherence to plastic under standard culture conditions; (2) expression of CD73, CD90, CD105 surface molecules in the absence of CD34, CD45, HLA-DR, CD14 or CD11b, CD79a or CD19; (3) differentiation capacity for osteoblasts, adipocytes and chondroblasts in vitro (1). These criteria have been established to standardize the isolation of MSCs from humans, but may not apply uniformly to other mammals.

\section{CELL THERAPIES USING MSCS IN SMALL ANIMALS}

In Figure 1, we describe the main effects of MSCs extracted from different sites in the preclinical acute rodent models, including IR AKI by renal pedicle clamping, chemotherapy AKI (cisplatin), and kidney transplantation itself $f^{2-9}$.

Despite the evidence that cell therapy with MSCs contributes to the improvement of AKI, some challenges need to be overcome in order for such therapy to be successfully established, such as defining the best route of administration, the number of cells per administration and also the number of injections, the best strategy for MSCs to migrate to acute and chronic kidney injury, understanding the interaction between MSCs and other tissue cells, and to identify adverse effects of MSCs (poorly differentiated in vivo and tumour formation).

Meta-analysis studies evaluating the therapeutic effect of MSCs in small animals in chronic and acute models of renal injury with variable administration (arterial, venous or renal) have shown beneficial effect for renal regeneration ${ }^{10}$. However, it is suggested that the arterial route enables renal regeneration more efficiently than the intravenous route. Intrave-

FIGURE 1. MAIN EFFECTS OF MESENCHYMAL STEM CELLS EXTRACTED FROM BONE MARROW, ADIPOSE TISSUE AND UMBILICAL CORD IN SEVERAL MODELS OF AKI BY RENAL PEDICLE CLAMPING ISCHEMIA-REPERFUSION, CHEMOTHERAPY (CISPLATIN) AND KIDNEY TRANSPLANTATION.

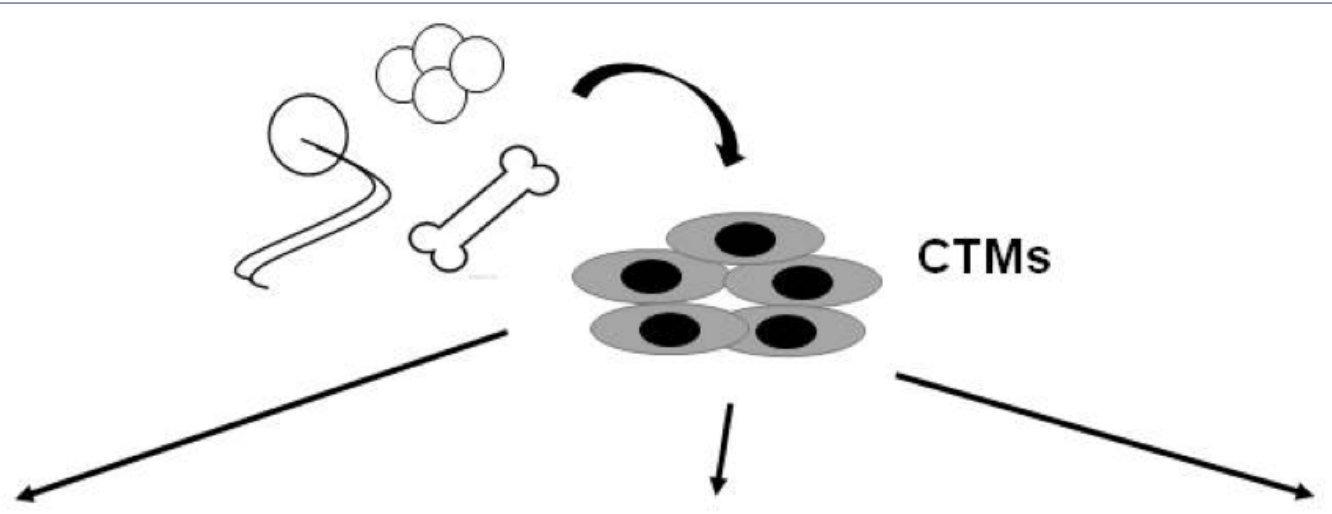

AKI induced by ischemia-reperfusion $A K I$ induced by chemotherapy (clamping of the renal pedicle)

$\uparrow$ Tubular cell proliferation

$\uparrow$ Tregs, IL-10, and macrophage M2

$\uparrow$ Klotho, HGF, VEGF, heme-oxygenase-1

$\uparrow$ Microvascular density

$\downarrow$ Creatinine, urea, KIM-1

$\downarrow$ Apoptosis (caspase 3), TNF-a, IL-1,

IL-10, IL-6, IFN-y

$\downarrow a-S M A$

$\downarrow$ Oxidative stress

$\downarrow$ Collagen deposition and interstitial fibrosis

$\downarrow$ Tissue damage (cisplatin)

$\uparrow$ Tubular cell proliferation

$\uparrow$ Animal survival

$\uparrow$ IL-10, VEGF, heme-oxigenase-I

$\downarrow$ Creatinine, urea, albuminuria

$\downarrow$ Apoptosis, TNF-a, IL-7, IL-10, IL-6

$\downarrow$ HGF, IGF-1, VEGF, p53

$\leftrightarrow H G F, T G F-01$, and IGF-1

$\downarrow$ Infiltration of T lymphocytes, neutro-

phils, and macrophages

$\downarrow$ Oxidative stress

$\downarrow$ Epithelium-mesenchymal transition

$\downarrow$ Interstitial fibrosis

$\downarrow$ Tissue damage
Renal transplantation

(Fisher -> Lewis, allogeneic)

$\uparrow$ Tregs

$\uparrow$ Renal graft survival

$\uparrow$ TSG-6 (TNF-inducible gene 6 protein)

$\downarrow$ Creatinine, urea

$\downarrow$ Infiltration of T lymphocytes and macrophages

$\downarrow \mathrm{MHC} I 1+, \mathrm{CD} 80+$, and $\mathrm{CD} 86+$ cells

$\downarrow C D 4+/ C C D 8+$ ratio

$\downarrow$ TGF-01

$\downarrow$ Interstitial fibrosis and tubular atrophy 
nously, cell number, multiple injections, and cell size increase the chance of pulmonary entrapment. Although local intraparenchymal administration also has a beneficial effect on renal repair, this route is less practical for clinical application, especially since renal disease is diffuse.

Another emerging approach to MSC administration-based therapies includes understanding the role of exosomes in tissue regeneration. Exosomes (30-40 to 100-120 nm) are vesicles naturally secreted by membranes and present ubiquitous distribution. These extracellular vesicles are considered important mediators of cell-to-cell communication, also mediating the effects of MSCs on target cells, such as the transfer of receptors, proteins, and genetic information (mRNA and microRNAs), as well as having direct stimulation in target-cell.

A key aspect that may adversely affect the therapeutic potential of MSCs is the inflammatory environment at the site of injury, as it may directly impact survival and incorporation of these cells into the injured tissue. Thus, M2 macrophage-derived anti-inflammatory cytokines (IL-10, TGF-ß1, TGF-ß3 and VEGF) favour the growth of MSCs, while M1 macrophage-derived proinflammatory cytokines (IL-1ß, IL -6, TNF- $\alpha$ and IFN- $\psi$ ) inhibit the growth of MSCs in vitro ${ }^{(11)}$. This observation indicates that the timing of MSC injection is crucial to the success of tissue repair.

However, further studies on renal models are still needed to evaluate this paradigm of transition from immune privilege to immunogenic state in MSC.

\section{CELL THERAPIES USING MSC IN HUMANS}

The number of registered clinical trials worldwide and applications for Investigational New Drugs (IND) submitted to the US Food and Drug Administration (FDA) have recently increased, as well as the diversity in donor and tissue sources and therapeutic purposes, despite the considerable heterogeneity in the protocols ${ }^{12}$. Most MSC trials included allogeneic cells occurring in the US, Europe, and China: phase 1 only (26\%), phase $1 / 2(40.6 \%)$, phase 2 only $(22.5 \%)$, phase $2 / 3(3.8 \%)$, phase $3(6.7 \%)$ and phase 4 (0.3\%). In 2019, 887 studies with H-MSCs were reported, 5\% of which in renal diseases only, including AKI, DKD (diabetic kidney diesease), kidney transplantation and nephritis, among others ${ }^{13}$.

Another key aspect of MSC-based therapy is the isolation of MSCs from individuals with chronic diseases, such as DM, for autologous transplantation. Thus, AT-MSC obtained from diabetic donors present higher levels of cellular senescence and apoptosis than AT-MSC obtained from non-diabetic individuals, as well as the reduced capacity of osteogenic and chondrogenic differentiation ${ }^{14}$. Similarly, type 2 diabetic patients treated with allogeneic UC-MSC $\left(1 \times 10^{6} / \mathrm{kg}\right)$, by intravenous injection followed by intrapancreatic endovascular injection, showed a reduction in glucose and glycated haemoglobin levels after a 12-month follow-up, as well as systemic inflammation markers (IL-1ß and IL-6) and T lymphocyte count (CD3 and CD4) ${ }^{14}$. C-peptide levels also improved and insulin requirement decreased by $\sim 30 \%$. Thus, allogeneic versus autologous transplantation based on

TABLE 1. CLINICAL OUTCOMES OF THE MAIN STUDIES ON MESENCHYMAL STEM CELLS AND ACUTE KIDNEY INJURY (AKI) DUE TO ISCHEMIA.

\begin{tabular}{|c|c|c|c|c|c|c|c|c|}
\hline Study & Stage & Type of AKI & $\begin{array}{l}\text { Number of } \\
\text { patients }\end{array}$ & $\begin{array}{l}\text { Type of } \\
\text { MSCs }\end{array}$ & $\begin{array}{l}\text { Site of extraction } \\
\text { of the MSCs / } \\
\text { Route of admin- } \\
\text { istration }\end{array}$ & $\begin{array}{l}\text { Dose (cells per } \\
\mathrm{kg} \text { of weight x } \\
106 \text { ) / number } \\
\text { of doses }\end{array}$ & $\begin{array}{l}\text { Time of infu- } \\
\text { sion of MSCs }\end{array}$ & Main findings \\
\hline $\begin{array}{l}\text { Togel et } \\
\text { al., } 2012\end{array}$ & I & $\begin{array}{l}\text { Ischemia } \\
\text { after cardiac } \\
\text { surgery }\end{array}$ & $\begin{array}{l}15, \text { separated } \\
\text { in low }(n=5), \\
\text { intermediate } \\
(n=5), \text { and } \\
\text { high }(n=5) \\
\text { doses }\end{array}$ & Allogenic & $\begin{array}{l}\text { Bone marrow / } \\
\text { Intra-aortic (su- } \\
\text { prarenal) }\end{array}$ & $\begin{array}{l}\text { Evaluation of } \\
\text { scaled doses } \\
\text { (quantity?) / } \\
\text { Single dose }\end{array}$ & During surgery & $\begin{array}{l}\text { - Administration of MSCs } \\
\text { is safe } \\
\text { - Reduction of AKI to 0\% } \\
\text { (versus 20\%) } \\
\text { - Reduction in } 40 \% \text { of the } \\
\text { time of hospitalization and } \\
\text { hospital readmission rates }\end{array}$ \\
\hline $\begin{array}{l}\text { Swami- } \\
\text { nathan et } \\
\text { al., } 2018\end{array}$ & 11 & $\begin{array}{l}\text { Ischemia } \\
\text { after cardiac } \\
\text { surgery }\end{array}$ & $\begin{array}{l}\text { 156, } 27 \text { centers: } \\
\text { - 67: MSCs } \\
\text { - 68: controls }\end{array}$ & Allogenic & $\begin{array}{l}\text { AC607 MSCs } \\
\text { (Allocure) - Bone } \\
\text { marrow / } \\
\text { Intra-aortic (su- } \\
\text { prarenal) }\end{array}$ & $\begin{array}{l}2.0 / \\
\text { Single dose }\end{array}$ & $\begin{array}{l}\text { 48h after } \mathrm{AKI} \\
\text { (preoperative } \\
\text { creatinine: } \\
1.3 \pm 0.6 \mathrm{mg} / \mathrm{dl} ; \\
\text { pre-treatment } \\
\text { creatinine } \\
2.1 \pm 0.7 \mathrm{mg} / \mathrm{dl} \text { ) }\end{array}$ & $\begin{array}{l}\text { - Administration of MSCs } \\
\text { is safe } \\
\text { - No difference in the num- } \\
\text { ber of days for recovery } \\
\text { from AKI } \\
\text { - No difference in mortality } \\
\text { after } 30 \text { days }\end{array}$ \\
\hline
\end{tabular}


TABLE 2. CLINICAL OUTCOMES OF THE MAIN STUDIES ON MESENCHYMAL STEM CELLS AND ACUTE KIDNEY INJURY DUE TO ISCHEMIA-REPERFUSION INJURY AND ACUTE DYSFUNCTION CAUSED BY REJECTION AFTER RENAL TRANSPLANTATION

\begin{tabular}{|c|c|c|c|c|c|c|c|c|}
\hline Study & $\begin{array}{l}\text { Induction } \\
\text { therapy }\end{array}$ & $\begin{array}{l}\text { Main- } \\
\text { tenance } \\
\text { therapy }\end{array}$ & $\begin{array}{l}\text { Number of } \\
\text { patients/type of } \\
\text { donor }\end{array}$ & $\begin{array}{l}\text { Type of } \\
\text { MSCs }\end{array}$ & $\begin{array}{l}\text { Site of } \\
\text { extraction } \\
\text { of the } \\
\text { MSCs / } \\
\text { Route of } \\
\text { adminis- } \\
\text { tration }\end{array}$ & $\begin{array}{l}\text { Dose (cells } \\
\text { per kg of } \\
\text { weight } \\
\text { x 106) / } \\
\text { number of } \\
\text { doses }\end{array}$ & $\begin{array}{l}\text { Time of infusion } \\
\text { of MSCs }\end{array}$ & Main findings \\
\hline $\begin{array}{l}\text { Perico et al. } \\
(2011)\end{array}$ & $\begin{array}{l}\text { rATG }(0.5 \mathrm{mg} / \\
\text { kg/day, days } \\
\text { 0-6; Basilix- } \\
\text { imab ( } 20 \text { mg, } \\
\text { days } 0 \text { and 4); } \\
\text { steroids (days } \\
\text { 0-7) }\end{array}$ & CSA, MMF & 2 / LRD & $\begin{array}{l}\text { Autolo- } \\
\text { gous }\end{array}$ & $\begin{array}{l}\text { Bone } \\
\text { marrow / } \\
\text { Intrave- } \\
\text { nous }\end{array}$ & $\begin{array}{l}\text { 1.7-2.0 / } \\
\text { single dose }\end{array}$ & Day 7 & $\begin{array}{l}\text { - } \uparrow \text { Tregs/Memory CD8 } \\
\text { lymphocytes ratio } \\
\text { - Pulse with MP in the third } \\
\text { week ( } \uparrow \text { creat) } \\
\text { - Absence of DSA class I and } \\
\text { class II }\end{array}$ \\
\hline $\begin{array}{l}\text { Tan et al. } \\
(2012)\end{array}$ & $\begin{array}{l}\text { Basiliximab } \\
(20 \text { mg, days } \\
0 \text { and } 4 \text { ) only } \\
\text { in the control } \\
\text { group }\end{array}$ & $\begin{array}{l}\text { ICN, MMF, } \\
\text { steroids: }\end{array}$ & $\begin{array}{l}\text { 159 / LRD: } \\
\text { - 53: standard } \\
\text { CNI group } \\
\text { - 53: standard } \\
\text { CNI group + } \\
\text { MSCs } \\
\text { - 53: } 80 \% \text { CNI } \\
\text { group + MSCs }\end{array}$ & $\begin{array}{l}\text { Autolo- } \\
\text { gous }\end{array}$ & $\begin{array}{l}\text { Bone } \\
\text { marrow / } \\
\text { Intrave- } \\
\text { nous }\end{array}$ & $1.0-2.0$ & Days 0 and 14 & $\begin{array}{l}-\downarrow \text { acute rejection in } 6 \\
\text { months }(\sim 7 \% \text { versus } 21.6 \%) \\
\text { - } \downarrow \text { viral infection }(\sim 9 \% \\
\text { versus } 29 \%) \\
\text { - no difference in eGFR in } 12 \\
\text { months }\end{array}$ \\
\hline $\begin{array}{l}\text { Perico et al. } \\
(2013)\end{array}$ & $\begin{array}{l}\text { rATG }(0.5 \mathrm{mg} / \\
\mathrm{kg} / \text { day, days } \\
\text { 0-6; steroids } \\
\text { (days 0-7) }\end{array}$ & CSA, MMF & 2 / LRD & $\begin{array}{l}\text { Autolo- } \\
\text { gous }\end{array}$ & $\begin{array}{l}\text { Bone } \\
\text { marrow / } \\
\text { Intrave- } \\
\text { nous }\end{array}$ & $\begin{array}{l}2.0 / \\
\text { single dose }\end{array}$ & Day 1 & $\begin{array}{l}\text { - } \text { Tregs/Memory CD8 } \\
\text { lymphocytes ratio } \\
\text { - Acute cellular rejection in } 1 \\
\text { patient }\end{array}$ \\
\hline $\begin{array}{l}\text { Reinders et } \\
\text { al. (2013) }\end{array}$ & $\begin{array}{l}\text { Basiliximab } \\
(20 \text { mg, days } 0 \\
\text { and } 4)\end{array}$ & $\begin{array}{l}\mathrm{CNI}, \mathrm{MMF} \\
\text { steroids }\end{array}$ & $6 / L R D$ & $\begin{array}{l}\text { Autolo- } \\
\text { gous }\end{array}$ & $\begin{array}{l}\text { Bone } \\
\text { marrow / } \\
\text { Intrave- } \\
\text { nous }\end{array}$ & $\begin{array}{l}1-2 / \\
2 \text { doses } \\
\text { with a 1-week } \\
\text { interval }\end{array}$ & $\begin{array}{l}6-10 \text { months: SCR } \\
\text { with } 4 \text { weeks or } \\
\text { SCR and/or IF/TA } \\
\text { with } 6-10 \text { months } \\
\text { in renal biopsy }\end{array}$ & $\begin{array}{l}\text { - improvement of tubulate in } \\
\text { the absence of IF/TA } \\
\text { - } 5 / 6 \text { patients: reduction of } \\
\text { specific lymphocyte prolifera- } \\
\text { tion to the in vitro donor }\end{array}$ \\
\hline $\begin{array}{l}\text { Peng et al. } \\
\text { (2013) }\end{array}$ & $\begin{array}{l}\text { Cyclophos- } \\
\text { phamide } 200 \\
\text { mg/day for } 3 \\
\text { days and MP } \\
\text { for } 3 \text { days }(750 \\
\mathrm{mg} / 250 \mathrm{mg} \\
\text { and } 250 \mathrm{mg} / \\
\text { day) }\end{array}$ & $\begin{array}{l}\text { TAC, MMF, } \\
\text { steroids }\end{array}$ & $\begin{array}{l}12 \text { / LRD } \\
\text { ( } 6 \text { controls and } \\
6 \text { with } 50 \% \text { TAC } \\
\text { and MSCs) }\end{array}$ & Allogeneic & $\begin{array}{l}\text { Bone } \\
\text { marrow / } \\
\text { Intrave- } \\
\text { nous }\end{array}$ & $\begin{array}{l}5.0 \text { via the } \\
\text { renal artery } \\
\text { and } 2.0 \text { intra- } \\
\text { venously } \\
/ 2 \text { doses }\end{array}$ & $\begin{array}{l}\text { Renal artery on } \\
\text { the day of the } \\
\text { transplant and } \\
\text { intravenous after } 1 \\
\text { month }\end{array}$ & $\begin{array}{l}\text { - no difference in acute } \\
\text { rejection and in eGFR after } 12 \\
\text { months } \\
\text { - MSCs group: higher levels } \\
\text { of B-lymphocytes after } 3 \\
\text { months } \\
\text { - Absence of chimerism after } \\
3 \text { months }\end{array}$ \\
\hline $\begin{array}{l}\text { Reinders et } \\
\text { al. (2015) } \\
\text { Stage Ib; } \\
\text { Neptune } \\
\text { Study }\end{array}$ & $\begin{array}{l}\text { Basiliximab } \\
(20 \text { mg, days } 0 \\
\text { and } 4)\end{array}$ & $\begin{array}{l}\mathrm{CNI}, \mathrm{MMF} \\
\text { steroids }\end{array}$ & 10 / LRD & Allogeneic & $\begin{array}{l}\text { Bone } \\
\text { marrow / } \\
\text { Intrave- } \\
\text { nous }\end{array}$ & $\begin{array}{l}2.5 \\
2 \text { doses } \\
\text { (1-week } \\
\text { interval) }\end{array}$ & 25 and 26 weeks & $\begin{array}{l}\text { - Ongoing study } \\
\text { - Primary outcomes: acute } \\
\text { rejection confirmed by biopsy } \\
\text { and renal graft loss } \\
\text { - Secondary outcomes: } \\
\text { fibrosis, DSA, immunological } \\
\text { tests, eGFR, opportunistic } \\
\text { infections }\end{array}$ \\
\hline $\begin{array}{l}\text { Mudrabettu } \\
\text { et al. (2015) }\end{array}$ & $\begin{array}{l}\text { rATG ( } 1 \mathrm{mg} / \\
\mathrm{kg} \text { ) for } 3 \text { con- } \\
\text { secutive days }\end{array}$ & $\begin{array}{l}\text { TAC, MMF, } \\
\text { steroids }\end{array}$ & 4/ LRD and LUD & $\begin{array}{l}\text { Autolo- } \\
\text { gous }\end{array}$ & $\begin{array}{l}\text { Bone } \\
\text { marrow / } \\
\text { Intrave- } \\
\text { nous }\end{array}$ & $\begin{array}{l}0.21-2.4 \\
/ 2 \text { doses }\end{array}$ & $\begin{array}{l}1 \text { day before } \\
\text { transplantation } \\
\text { and } 1 \text { month after } \\
\text { transplantation }\end{array}$ & $\begin{array}{l}\text { - No early or late dysfunction } \\
\text { of renal graft } \\
\text { - Absence of viral infection } \\
\text { - } \uparrow \text { Tregs } \\
\text { - } \downarrow \text { proliferation of CD4 } \\
\text { lymphocytes }\end{array}$ \\
\hline $\begin{array}{l}\text { Pan et al. } \\
(2016)\end{array}$ & $\begin{array}{l}\text { Cyclophos- } \\
\text { phamide } 200 \\
\text { mg/day for } 3 \\
\text { days and MP } \\
\text { for } 3 \text { days }(750 \\
\mathrm{mg} / 250 \mathrm{mg} \\
\text { and } 250 \mathrm{mg} / \\
\text { day) }\end{array}$ & $\begin{array}{l}\text { TAC, MMF, } \\
\text { steroids }\end{array}$ & $\begin{array}{l}32 \\
\text { (16 controls and } \\
16 \text { treated with } \\
50 \% \text { TAC and } \\
\text { MSCs) / LRD }\end{array}$ & Allogeneic & $\begin{array}{l}\text { Bone mar- } \\
\text { row/ Renal } \\
\text { artery and } \\
\text { intrave- } \\
\text { nous }\end{array}$ & $\begin{array}{l}5.0 \text { via } \\
\text { renal artery } \\
\text { and } 2.0 \text { intra- } \\
\text { venously } \\
/ 2 \text { doses }\end{array}$ & $\begin{array}{l}\text { Renal artery on } \\
\text { the day of the } \\
\text { transplant and } \\
\text { intravenous after } 1 \\
\text { month }\end{array}$ & $\begin{array}{l}\text { - No difference in acute } \\
\text { rejection, renal graft survival, } \\
\text { serum creatinine, and eGFR } \\
\text { - Absence of changes in re- } \\
\text { sponses to donor alloantigens } \\
\text { in vitro } \\
\text { - Immunophenotyping com- } \\
\text { parable of subpopulations of } \\
\text { Tlymphocytes }\end{array}$ \\
\hline $\begin{array}{l}\text { Sun et al. } \\
(2018)\end{array}$ & $\begin{array}{l}\text { rATG ( } 50 \\
\text { mg/day, for } 3 \\
\text { consecutive } \\
\text { days) }\end{array}$ & $\begin{array}{l}\mathrm{CNI}, \mathrm{MMF} \\
\text { steroids }\end{array}$ & $\begin{array}{l}42 \\
\text { ( } 21 \text { controls and } \\
21 \text { treated with } \\
\text { and MSCs) / DD }\end{array}$ & Allogeneic & $\begin{array}{l}\text { Umbilical } \\
\text { cord/ In- } \\
\text { travenous } \\
+ \text { Renal } \\
\text { artery }\end{array}$ & $\begin{array}{l}2.0 \text { Intrave- } \\
\text { nously and } \\
5.0 \text { via renal } \\
\text { artery } \\
\text { / single doses } \\
\text { on each route }\end{array}$ & $\begin{array}{l}\text { Intravenous: } 30 \\
\text { minutes before the } \\
\text { renal transplanta- } \\
\text { tion/ Renal artery } \\
\text { at the time of } \\
\text { transplantation }\end{array}$ & $\begin{array}{l}\text { - No difference in delayed } \\
\text { renal graft function, acute } \\
\text { rejection, eGFR, patient and } \\
\text { renal graft survival after } 12 \\
\text { months }\end{array}$ \\
\hline
\end{tabular}




\begin{tabular}{|c|c|c|c|c|c|c|c|c|}
\hline Study & $\begin{array}{l}\text { Induction } \\
\text { therapy }\end{array}$ & $\begin{array}{l}\text { Main- } \\
\text { tenance } \\
\text { therapy }\end{array}$ & $\begin{array}{l}\text { Number of } \\
\text { patients/type of } \\
\text { donor }\end{array}$ & $\begin{array}{l}\text { Type of } \\
\text { MSCs }\end{array}$ & $\begin{array}{l}\text { Site of } \\
\text { extraction } \\
\text { of the } \\
\text { MSCs / } \\
\text { Route of } \\
\text { adminis- } \\
\text { tration }\end{array}$ & $\begin{array}{l}\text { Dose (cells } \\
\text { per kg of } \\
\text { weight } \\
\text { x 106) / } \\
\text { number of } \\
\text { doses }\end{array}$ & $\begin{array}{l}\text { Time of infusion } \\
\text { of MSCs }\end{array}$ & Main findings \\
\hline $\begin{array}{l}\text { Vanikar et al. } \\
\text { (2018) }\end{array}$ & $\begin{array}{l}\text { Protocol for } \\
\text { induction of } \\
\text { tolerance: } \\
\text { non-mye- } \\
\text { loablative } \\
\text { therapy with } \\
\text { Bortezomib, } \\
\text { MP, rATG, and } \\
\text { Rituximab }\end{array}$ & $\begin{array}{l}\text { No con- } \\
\text { ventional } \\
\text { immuno- } \\
\text { suppression }\end{array}$ & $10 /$ LRD & Allogeneic & $\begin{array}{l}\text { Hema- } \\
\text { topoietic } \\
\text { cells of the } \\
\text { bone mar- } \\
\text { row and } \\
\text { adipose } \\
\text { tissue / } \\
\text { Intraportal }\end{array}$ & $\begin{array}{l}0.22 \pm 0.16 \\
\text { of CD } 34+ \\
\text { cells from } \\
\text { bone marrow } \\
\text { mixed with } \\
0.19 \pm 0.09 \text { of } \\
\text { MSCs of adi- } \\
\text { pose tissue }\end{array}$ & $\begin{array}{l}14 \text { days before the } \\
\text { transplant }\end{array}$ & $\begin{array}{l}\text { - Acute cellular rejection: } \\
3 \text { patients ( } 155 \text { days, } 33.4 \\
\text { months and } 1.4 \\
\text { year) } \\
\text { - Patient survival: } 100 \% \text { (2 } \\
\text { years), } 90 \% \text { ( } 3 \text { years), and } \\
80 \% \text { (6 years): } n=1 \text { pneumo- } \\
\text { nia; } n=1 \text { sudden death and } \\
\text { chronic graft dysfunction } \\
\text { - Renal graft survival cen- } \\
\text { sored to death in } 6 \text { years: } \\
90 \% \text { ( }=1 \text { loss due to IF/TA) } \\
\text { - } 2 \text { patients with DSA, but } \\
\text { without graft dysfunction } \\
\text { - } 5 \text { with conventional immu- } \\
\text { nosuppression and } 2 \text { with } \\
\text { mycophenolate } \\
\text { - Serum creatine: } 1.44 \pm 0.41 \\
\text { mg/dl after } 6 \text { years }\end{array}$ \\
\hline $\begin{array}{l}\text { Erpicum et } \\
\text { al. (2019) }\end{array}$ & $\begin{array}{l}\text { Basiliximab } \\
(20 \mathrm{mg} \text {, days } 0 \\
\text { and } 4 \text { ) }\end{array}$ & $\begin{array}{l}\text { TAC, MMF } \\
\text { and steroids } \\
\text { (39\% dis- } \\
\text { continued) }\end{array}$ & $\begin{array}{l}20 \\
\text { (10 controls and } \\
10 \text { treated with } \\
\text { MSCs) / } \\
\text { DF }\end{array}$ & Allogeneic & $\begin{array}{l}\text { Bone } \\
\text { marrow / } \\
\text { Intrave- } \\
\text { nous }\end{array}$ & $\begin{array}{l}\text { mean } 2.4 \\
(2.0-2.6) \\
\text { / single dose }\end{array}$ & $\begin{array}{l}3 \pm 2 \text { days after the } \\
\text { transplant } \\
(2-5 \text { days varia- } \\
\text { tion) }\end{array}$ & $\begin{array}{l}\text { - } 1 \text { patient with acute myo- } \\
\text { cardial infarction } 3 \text { hours after } \\
\text { infusion of MSCs } \\
-\uparrow \text { Tregs in } 30 \text { days, but no } \\
\text { difference after } 1 \text { year } \\
\text { - No difference in prolifera- } \\
\text { tion of B lymphocytes } \\
\text { - No difference in acute } \\
\text { rejection and opportunistic } \\
\text { infections } \\
\text { - No difference in eGFR after } \\
1 \text { year } \\
-4 \text { patients developed anti- } \\
\text { bodies anti-MSCs (only } 1 \text { with } \\
\text { MFI > 1,500) }\end{array}$ \\
\hline
\end{tabular}

MSCs = Mesenchymal Stem Cells; rATG = Rabbit anti-thymocyte globulin; CSA = Cyclosporine; MMF = Mycophenolate Mofetil; LRD = Living related donation; LUD= Living unrelated donation; MP = Methylprednisolone; DSA = Donor Specific Antibody; CNI = Calcineurin inhibitor; eGFR = Estimated Glomerular Filtration Rate; SCR = Subclinical rejection; IF/TA = Interstitial fibrosis/Tubular atrophy; TAC = Tacrolimus; DD = Deceased donor; MFI = Mean Fluorescence intensity

the use of MSCs requires further investigation in the setting of DKD. On the other hand, in patients with ischemic cardiomyopathy, allogeneic and autologous BM-MSC were equally safe and effective ${ }^{15}$.

In addition, some obstacles need to be overcome to achieve greater safety in MSC-based therapies such as cytogenetic aberrations observed during the propagation of these cells in culture. In humans, malignant transformation of MSCs has not been described in vivo so far in clinical trials. Another important aspect that should be taken into account in MSC cell therapy is the fact that its beneficial effect may be neglected by the occurrence of adipogenic differentiation during long-term follow-up, which may contribute to glomerulosclerosis.

In tables 1 and 2, we describe the main studies with MSCs in humans in the AKI scenario ${ }^{16,17}$ and after kidney transplantation ${ }^{18-28}$, respectively. In Table 2, we describe both studies that evaluated safety and efficacy at the initial moment of transplantation and also at the later period. Currently, there are more than ten ongoing clinical studies involving a significant number of patients undergoing kidney transplantation, which means more than one thousand individuals ${ }^{29}$. We highlight an ongoing clinical study with the inclusion of individuals undergoing renal transplantation and injection of two doses of autologous MSCs at weeks 6 and 7, and alemtuzumab induction followed by maintenance with everolimus and discontinuation of Tacrolimus from week 8 onwards ${ }^{30}$.

An important point for the use of MSCs after kidney transplantation is the interaction between immunosuppressive drugs and the function of these cells. In vitro studies have shown that all immunosuppressant drugs (steroids, cyclosporine, sirolimus and mycophenolate) interfere in some way with the function of MSCs, leading to reduced production of 
trophic factors (HGF and VEGF) and TSG-6, which has immunomodulatory properties and antiapoptotic properties ${ }^{31}$.

\section{NEW PERSPECTIVES}

Preconditioning or gene modifications of MSCs

Several approaches have been suggested to increase the efficiency of cell therapy with MSCs, such as preconditioning or gene modifications.

\section{Preconditioning of MSCs}

MSCs are generally grown in a $21 \%$ oxygen environment. However, physiologically, MSCs are found in an environment with a much lower oxygen tension (1\% to $7 \%)$. Thus, the cultivation or preconditioning of MSCs in a hypoxic environment with $2 \%$ or $5 \%$ oxygen allows these cells to remain multipotent and have greater proliferative and migratory capacity, as well as lower senescence rates ${ }^{32}$. In addition, hypoxia-preconditioned MSCs do not differentiate into tumour-associated fibroblasts in vitro and do not induce tumours in vivo.

In order to reduce the heterogeneity of the MSC profile, which is defined by the different isolation and culture protocols, the preconditioning of these cells with proinflammatory factors has been the focus of investigation. Thus, preconditioning of MSCs by stimulating IFN- $\psi$, TNF- $\alpha$, PGE2 and nitric oxide mitigated the heterogeneous behaviour of MSCs in T lymphocyte proliferation trials and late type hypersensitivity response ${ }^{33}$.

\section{MSCs: gene carriers or gene modifications}

Due to their migratory capacity to lesion sites, MSCs represent a robust platform for "delivery" of genes associated with regeneration and repair of renal tissue, working as a "Trojan Horse". Thus, several genes associated with trophic factors have been studied for these purposes, IGF-1, HGF, EGF or VEGF, since they are renoprotective ${ }^{7,34}$.

Our group has been studying two genes, HGF and klotho, which have promising therapeutic potential in the future. We are modifying MSCs with these genes and will be injecting them into acute and chronic models of kidney injury.

In the context of IR or cisplatin-induced AKI, HGF is associated with increased tubular epithelial cell proliferation and migration, as well as lower
$\alpha$-SMA expression, fibrosis, and apoptosis. In chronic models such as murine DKD, HGF gene therapy increased the expression of SDF-1, which is the ligand of CXCR4 and, consequently, bone marrow cell migration to the kidney. Consequently, there was an improvement in proteinuria, a reduction in glomerulosclerosis (lower collagen I and IV deposition, and fibronectin) and TGF- $\beta 1$ levels, a reduction in glucose and GLUT1-mediated glucose uptake, thus reducing oxidative stress. Similarly, in the murine Lewis mouse transplant model, HGF also reduced tubulointerstitial fibrosis, glomerulosclerosis and inflammation, leading to increased renal graft and animal survival.

Klotho is highly expressed in the distal tubule of the kidney ${ }^{35}$. It is a co-receptor for fibroblast growth factor-23 (FGF-23) and participates in mineral homeostasis through interaction with other hormones such as parathyroid hormone (PTH) and 1,25-(OH $)_{2}$ vitamin D3 in various tissues such as the kidneys, bones, intestines and parathyroid gland. There is a molecular signature of murine model klotho deficiency and CKD in humans, both related to serum creatinine values related to klotho expression in renal tissue, serum phosphorus and FGF23 values, atherosclerosis and ectopic calcification. In the kidneys, the soluble form of klotho has several effects and, therefore, therapeutic targets, such as antioxidant effects on cells (decreased senescence and apoptosis, as well as increased autophagy), inhibition of fibrosis, phosphorus reduction and FGF23, proangiogenic agents and maintenance of the stem cell reservoir, as well as reducing myocardial remodelling. Similarly, understanding the factors that decrease klotho expression in the kidney is equally important for establishing combined therapies to mitigate AKI damage and reduce CKD progression and, consequently, renal fibrosis. Factors that decrease kidney klotho expression include reduced kidney functional mass, abnormal cytokine production ( $\uparrow$ TNF- $\alpha$ and $\uparrow$ IFN- $\psi$ ), increased oxidative stress ( $\uparrow$ lipid peroxidation and hydrogen peroxide), activation of the renin-angiotensin-aldosterone system (RAAS), reduction of vitamin D3, alteration of bone metabolism (hyperphosphatemia) and uremic toxins ( $\uparrow$ indoxyl sulphate).

In AKI patients, there is a proportional reduction in klotho expression according to the severity of the lesion. Thus, the administration of klotho protein, as well as the study of drugs that increase its production (statin and RAAS blockers, for example), reacti- 
vation of endogenous expression of klotho by epigenetic mechanisms (demethylation and deacetylation) and/or cell therapy itself represent promising strategies. Thus, UC-MSC injection in rats subjected to IR injury restores kidney klotho expression, whereas genetically modified klotho-adenovirus MSCs lead to reduction of morphological and structural damage in the same model.

Other genetic modifications of MSCs, which are also quite promising in the context of AKI, include overexpression of erythropoietin, CXCR4, CTLA4Ig and IL-10/selectin, as well as transfection of biological drug-containing minicircles such as Etanercept, which is a TNF- $\alpha$ blocker and the transfection of nanoparticles containing iron oxide, polymers and plasmids.

\section{Renal tissue-derived progenitors/stem cells}

Several progenitors/stem cells specific to renal tissue have been studied in the literature, mainly in preclinical studies, and evaluated in acute and chronic models.

Recently our group demonstrated that c-Kit ${ }^{+}$cells present in renal tissues have cardinal progenitor/ stem cell properties, such as the ability to differentiate in different lineages of the mesodermal and ectodermal layers, clonogenicity, self-renewal and therapeutic potential in the AKI by IR model and acute puromycin-induced nephrotic syndrome in rats ${ }^{2,36}$. In addition to paracrine effects, c-Kit cells have been incorporated around $10 \%$ in various renal compartments, such as tubular, vascular and glomerular, making them promising candidates for cell therapy. There is interest in defining whether MSCs can modulate c-Kit stem/progenitor cells in vivo or whether the combined infusion of these cells can have a more robust effect on renal tissue regeneration or interruption of AKI and CKD progression. Recently, we have reported the expression of c-Kit cells in kidneys of deceased donors ${ }^{37}$, so future studies are needed to demonstrate the therapeutic potential of these cells in preclinical and human models.

Other approaches to renal regeneration: embryonic stem cells, inducible pluripotent stem cells (iPSCs), organoids and renal decellularisation

Embryonic stem cells and inducible pluripotent stem cells are capable of originating the three types of embryonic layers, giving rise to any cell type when appropriate culture conditions are applied. Modest clinical trials are underway with these cells ${ }^{13}$.

IPSCs have been studied as a model for the re-creation of renal diseases and culture plate, studies of signalling pathways, therapeutic tests, drug screening ${ }^{38}$, and the generation of renal and organoid progenitors that can be used for renal regeneration and for a better understanding of the pathways involved in renal development and pathobiological processes. Other robust platforms that can be used for this purpose include 3D printing techniques and kidney-on-a-chip microfluidic technology. Renal decellularisation presents a therapeutic alternative and its use has already been successfully tested in small animals, combined with recellularisation with endothelial cells, renal foetal cells and MSCs. Renal decellularisation studies in larger animals are needed, and in the future, kidney from pigs or from expanded criterion donors may be used as an alternative or as a bridge to kidney transplantation.

\section{CHALLENGES TO CELL THERAPY}

Heterogeneity of AKI causes.

Each scenario promotes a type of molecular signature, requiring specific interventions for each in order to regain homeostasis. Understanding the biological environment in which cells are being inserted is extremely important in order to design the best approach beforehand and to understand possible therapeutic outcomes after therapy.

\section{High structural complexity of kidneys.}

The kidneys are formed from two germinal foci, the ureteric bud and the metanephric mesenchyme, which differ in more than 30 different cell types in the adult kidney. Thus, an intense association between epithelium and vascular tissue is formed in various functions for hemodynamic balance and electrolyte balance.

\section{Complicating factors of MSCs therapy itself \\ Exact understanding of the type of cell used}

The acronym "mesenchymal (stromal) stem cell" refers to a diverse set of cell types and is therefore it is inaccurate. From the moment of cell extraction to the choice of tissue source, they already interfere with potential, function and transcripts. 


\section{Administration timing}

Ideally, MSCs should be injected at the very beginning of AKI changes. The difficulty of this moment is the silent form of the lesion, without presenting typical symptoms. Good biomarkers should be established to identify as soon as possible the onset of AKI, quickly and early. Once this ideal moment of action is identified, it is necessary to have the cells ready for injection, requiring very well structured logistics and making it difficult to use autologous cells (due to the time of preparation and expansion in culture).

\section{Compatibility between injected cells and receptors}

Despite the well-established notion of MHC-II expression by MSCs, further understanding of the mechanisms related to the immune privilege or immunosuppression ability of MSCs is needed, which may be crucial for the successful integration of cells into the patient and the success of the therapy, as it happens in cases of bone marrow transplantation. This knowledge is even more necessary in the clinical setting, which often requires multiple dose applications to achieve the expected outcome in chronic diseases.

In favour of the use of autologous MSCs, a meta-analysis in heart failure patients favoured increased exercise capacity, left ventricular ejection fraction, quality of life and reduced mortality and hospital readmission rates ${ }^{39}$. In another meta-analysis, treatment with whole bone marrow autologous cells (dose ranged from $382.6 \pm 10^{7}$ to $2.8 \pm 1.9 \times 10^{9}$ ) was effective for reducing glycated haemoglobin $\left(\mathrm{HbA}_{1 \mathrm{c}}\right)$ by $1.18 \%$ and for reducing the need for insulin at 3,6 , 9 and 12 months after treatment ${ }^{40}$.

There is recent evidence that allogeneic MSCs would be as effective as autologous MSCs in improving the final diastolic volume and left ventricular ejection fraction of patients with ischemic cardiomyopathy ${ }^{15}$. Importantly, allogeneic MSCs did not promote immune response at the receptors. In renal transplant patients, injections of autologous ${ }^{18}$ and allogeneic ${ }^{26}$ MSCs were also considered safe.

Understanding the specific action mechanisms of different MSCs types

There is a lack of skill specification data that MSCs present according to their tissue origin, for the proper adaptation of the cell type to the clinical picture to be applied. Important qualifications of MSCs such as cell-type differentiation of damaged target tissue, immunosuppression and anti-inflammatory action have been tested in vitro and do not necessarily accurately predict actual clinical potency in each scenario. An interesting study has shown that for the immunosuppressive action of MSCs in patients with host disease against donor, cytotoxic immune attack of the host patient against injected MSCs is essential, inducing them to apoptosis. Patients who responded best to therapy were the ones with the highest cytotoxicity against injected MSCs. According to the evaluation of the existing literature, the decision of the moment of injection of the cells determines the microenvironment that they will find. MSCs, in response to the inflammatory microenvironment, activate their own anti-inflammatory mechanisms, defining the resultant patient-cell therapy interaction. This may explain some negative results obtained by clinical trials. For example, patients who received MSCs prior to kidney transplantation showed no difference from the control group in relation to the common adverse effects of the procedure, which can be explained by the microenvironment without the inflammatory IR insult installed and, consequently, the lack of activation of MSCs to the anti-inflammatory pattern ${ }^{41}$.

Monitoring patients beforehand in order to identify these more responsive subgroups and understand the timing of the most appropriate pathogenesis for cell administration is extremely valuable in achieving the desired efficacy of the therapy.

\section{Data from clinical trials are in progress}

Most clinical studies are based on safety and efficacy outcomes and are not designed with large numbers of patients and have heterogeneity in injection dose and frequency. However, the occurrence of adverse events after treatment with MSCs does not appear to be different from the control group.

\section{Cell dose per individual: uncertainties}

There is a detrimental mismatch between data from preclinical and clinical studies regarding the appropriate amount for cell therapy with MSCs. Commonly, in rodents, the intravenous dose is 50 million/ $\mathrm{kg} /$ weight. In humans, MSCs are usually transfused around 1-2 million $/ \mathrm{kg} /$ weight. However, weight adjustment may not be the best measure for comparing humans and rodents for therapeutic perspectives. Even so, considering that they respect the same biological mechanism of action and that the effects are 
dose-dependent, this difference in methodology imposes a negative bias in clinical practice due to the lower dose used in humans.

Administration route: more effective biodistribution for the desired outcome

There is still no consensus on the best route of injection of MSCs in preclinical and clinical trials, and the intravenous route is widely used. Depending on the choice, there is a different dynamics of cell distribution in the body, affecting the mechanism of action and possibly the clinical outcome. Among the options, some choices have practical methodological ease in the routine application and also in the transition to clinical use, such as the extravascular (intraperitoneal, intramuscular and subcutaneous) pathways. Testing these pathways, it has already been shown that MSCs, when acting in a systemic manner, also end up benefiting the organ affected by the disease in question, even with the distance ${ }^{42}$.

\section{Regulated clean room}

It is necessary to define production standards according to the disease and the type of patient. Isolation method, culture time and environment composition can all affect the potency and quality of the final product of MSCs. It is suggested that MSCs be injected until passage $(\mathrm{P}) 2$, when the amount of cells obtained is also sufficient. It is still necessary to consider the costs and complexity of these processes, and it is extremely important to evaluate measures that enable large-scale production at low cost, as it is done in the processes of blood transfusion centres.

One of the challenges of cell therapy with MSCs is a better understanding of the occurrence of chromosomal alterations, which, although rare $(n=1 / 152)$, leads to the disposal of $\mathrm{MSCs}^{43}$. Thus, the genomic integrity of MSCs, assessed by karyotype, should always be considered, although the ideal moment, if soon after cell collection, in which passage or before infusion, is still a matter of debate.

Finally, the additional characterization of MSC manufactured products is essential for a better understanding of the phenotypic characteristics and their subpopulations, as well as for the evaluation of their therapeutic potential.

\section{CONCLUSIONS}

Cellular therapy with MSCs has benefits in preclinical studies of AKI through various mechanisms, such as anti-inflammatory, antiapoptotic, oxidative anti-stress, antifibrotic, immunomodulatory and proangiogenic. Such benefits may also explain many of the positive effects of that therapy on humans.

\section{Authors' contribution:}

C.S.S.; P.E.S.S.; M.T.B.R., A.O.L. wrote the review; E.B.R. wrote the review and gave the final approval.

\section{Acknowledgment}

This work was supported by the Fundação de Amparo à Pesquisa do Estado de São Paulo (Fapesp) for Christian Sávio Silva (process 2017/18072-9), Poliana Evelyn Soinski de Sousa (process 2018/24562-1) and Érika Bevilaqua Rangel (process 2017/23195-2), in addition to the European Foundation for the Study of Diabetes (EFSD) for Érika Bevilaqua Rangel.

\section{REFERENCES}

1. Dominici M, Le BK, Mueller I, Slaper-Cortenbach I, Marini F, Krause D, et al. Minimal criteria for defining multipotent mesenchymal stromal cells. The International Society for Cellular Therapy position statement. Cytotherapy 2006; 8:315-317.

2. Rangel EB, Gomes SA, Dulce RA, Premer C, Rodrigues CO, Kanashiro-Takeuchi RM, et al. C-kit(+) cells isolated from developing kidneys are a novel population of stem cells with regenerative potential. Stem Cells 2013; 31:1644-1656.

3. Fleig SV., Humphreys BD. Rationale of mesenchymal stem cell therapy in kidney injury. Nephron Clin Pract 2014; 127:75-80

4. Rowart P, Erpicum P, Detry O, Weekers L, Gregoire C, Lechanteur C, et al. Mesenchymal Stromal Cell Therapy in Ischemia/Reperfusion Injury. J Immunol Res 2015; 2015:602597-

5. Casiraghi F, Perico N, Cortinovis M, Remuzzi G. Mesenchymal stromal cells in renal transplantation: opportunities and challenges. Nat Rev Nephrol 2016; 12:241-253.

6. Veceric-Haler Z, Cerar A, Perse M. (Mesenchymal) Stem Cell-Based Therapy in Cisplatin-Induced Acute Kidney Injury Animal Model: Risk of Immunogenicity and Tumorigenicity. Stem Cells Int 2017; 2017:7304643-

7. Torres CA, Daniele C, Gamez C, Medina BS, Pastene DO, Nardozi D, et al. Stem/Stromal Cells for Treatment of Kidney Injuries With Focus on Preclinical Models. Front Med (Lausanne) 2018; 5:179- 
8. Yun CW., Lee SH. Potential and Therapeutic Efficacy of Cell-based Therapy Using Mesenchymal Stem Cells for Acute/chronic Kidney Disease. Int I Mol Sci 2019; 20:

9. Yin K, Wang S, Zhao RC. Exosomes from mesenchymal stem/stromal cells: a new therapeutic paradigm. Biomark Res 2019; 7:8-

10. Wang $Y, H e \mid$, Pei $X$, Zhao W. Systematic review and meta-analysis of mesenchymal stem/stromal cells therapy for impaired renal function in small animal models. Nephrology (Carlton ) 2013; 18:201-208.

11. Freytes DO, Kang JW, Marcos-Campos I, Vunjak-Novakovic G. Macrophages modulate the viability and growth of human mesenchymal stem cells. | Cell Biochem 2013; 114:220-229.

12. Trounson A., McDonald C. Stem Cell Therapies in Clinical Trials: Progress and Challenges. Cell Stem Cell 2015; 17:11-22.

13. Rota C, Morigi M, Imberti B. Stem Cell Therapies in Kidney Diseases: Progress and Challenges. Int I Mol Sci 2019; 20:

14. Cramer C, Freisinger E, Jones RK, Slakey DP, Dupin CL, Newsome ER, et al. Persistent high glucose concentrations alter the regenerative potential of mesenchymal stem cells. Stem Cells Dev 2010; 19:1875-1884.

15. Hare JM, Fishman JE, Gerstenblith G, DiFede Velazquez DL, Zambrano IP, Suncion VY, et al. Comparison of allogeneic vs autologous bone marrow-derived mesenchymal stem cells delivered by transendocardial injection in patients with ischemic cardiomyopathy: the POSEIDON randomized trial. |AMA 2012; 308:2369-2379.

16. Togel FE., Westenfelder $C$. Kidney protection and regeneration following acute injury: progress through stem cell therapy. Am J Kidney Dis 2012; 60:1012-1022

17. Swaminathan M, Stafford-Smith M, Chertow GM, Warnock DG, Paragamian V, Brenner RM, et al. Allogeneic Mesenchymal Stem Cells for Treatment of AKI after Cardiac Surgery. J Am Soc Nephrol 2018; 29:260-267.

18. Perico N, Casiraghi F, Introna M, Gotti E, Todeschini M, Cavinato RA, et al. Autologous mesenchymal stromal cells and kidney transplantation: a pilo study of safety and clinical feasibility. Clin | Am Soc Nephrol 2011; 6:412-422.

19. Tan J, Wu W, Xu X, Liao L, Zheng F, Messinger S, et al. Induction therapy with autologous mesenchymal stem cells in living-related kidney transplants: a randomized controlled trial. JAMA 2012; 307:1169-1177.

20. Perico N, Casiraghi F, Gotti E, Introna M, Todeschini M, Cavinato RA, et al. Mesenchymal stromal cells and kidney transplantation: pretransplant infusion protects from graft dysfunction while fostering immunoregulation. Transpl Int 2013; 26:867-878.

21. Reinders ME, de Fijter IW, Roelofs H, Bajema IM, de Vries DK, Schaapherder AF, et al. Autologous bone marrow-derived mesenchymal stromal cells for the treatment of allograft rejection after renal transplantation: results of a phase I study. Stem Cells Transl Med 2013; 2:107-111.

22. Peng Y, Ke M, Xu L, Liu L, Chen X, Xia W, et al. Donor-derived mesenchyma stem cells combined with low-dose tacrolimus prevent acute rejection after renal transplantation: a clinical pilot study. Transplantation 2013; 95:161-168.

23. Reinders ME, Dreyer GJ, Bank JR, Roelofs H, Heidt S, Roelen DL, et al. Safety of allogeneic bone marrow derived mesenchymal stromal cell therapy in renal transplant recipients: the neptune study. J Transl Med 2015; 13:344-

24. Mudrabettu C, Kumar V, Rakha A, Yadav AK, Ramachandran R, Kanwa DB, et al. Safety and efficacy of autologous mesenchymal stromal cells transplantation in patients undergoing living donor kidney transplantation: a pilot study. Nephrology (Carlton ) 2015; 20:25-33.

25. Pan GH, Chen Z, Xu L, Zhu IH, Xiang P, Ma |l, et al. Low-dose tacrolimus combined with donor-derived mesenchymal stem cells after renal transplantation: a prospective, non-randomized study. Oncotarget 2016; 7:12089-12101.

26. Sun Q, Huang Z, Han F, Zhao M, Cao R, Zhao D, et al. Allogeneic mesenchymal stem cells as induction therapy are safe and feasible in renal allografts: pilot results of a multicenter randomized controlled trial. | Transl Med 2018; 16:52-

27. Vanikar AV, Trivedi HL, Thakkar UG. Six years' experience of tolerance induction in renal transplantation using stem cell therapy. Clin Immunol 2018; 187:10-14.

28. Erpicum P, Weekers L, Detry O, Bonvoisin C, Delbouille MH, Gregoire C, et al. Infusion of third-party mesenchymal stromal cells after kidney transplantation: a phase I-II, open-label, clinical study. Kidney Int 2019; 95:693-707.

29. Kaundal U, Bagai U, Rakha A. Immunomodulatory plasticity of mesenchymal stem cells: a potential key to successful solid organ transplantation. ] Transl Med 2018; 16:31-

30. Reinders ME, Bank IR, Dreyer Gl, Roelofs H, Heidt S, Roelen DL, et al. Autologous bone marrow derived mesenchymal stromal cell therapy in combination with everolimus to preserve renal structure and function in renal transplant recipients. J Transl Med 2014; 12:331-

31. Javorkova E, Vackova J, Hajkova M, Hermankova B, Zajicova A, Holan V, et al. The effect of clinically relevant doses of immunosuppressive drugs on human mesenchymal stem cells. Biomed Pharmacother 2018; 97:402-411.

32. Feng Y, Zhu M, Dangelmajer S, Lee YM, Wijesekera O, Castellanos CX, et al. Hypoxia-cultured human adipose-derived mesenchymal stem cells are non-oncogenic and have enhanced viability, motility, and tropism to brain cancer. Cell Death Dis 2014; 5:e1567-

33. Szabo E, Fajka-Boja R, Kriston-Pal E, Hornung A, Makra I, Kudlik G, et al. Licensing by Inflammatory Cytokines Abolishes Heterogeneity of Immunosuppressive Function of Mesenchymal Stem Cell Population. Stem Cells Dev 2015; 24:2171-2180.

34. Paulini ], Higuti E, Bastos RM, Gomes SA, Rangel EB. Mesenchymal Stem Cells as Therapeutic Candidates for Halting the Progression of Diabetic Nephropathy. Stem Cells Int 2016; 2016:9521629-

35. Hu MC, Kuro-o M, Moe OW. Renal and extrarenal actions of Klotho. Semin Nephrol 2013; 33:118-129.

36. Rangel EB, Gomes SA, Kanashiro-Takeuchi R, Saltzman RG, Wei C, Ruiz P, et al. Kidney-derived c-kit(+) progenitor/stem cells contribute to podocyte recovery in a model of acute proteinuria. Sci Rep 2018; 8:14723-

37. Gomes SA, Hare JM, Rangel EB. Kidney-Derived c-Kit(+) Cells Possess Regenerative Potential. Stem Cells Transl Med 2018; 7:317-324.

38. Freedman BS. Modeling Kidney Disease with iPS Cells. Biomark Insights 2015; 10:153-169

39. Fisher SA, Doree C, Mathur A, Martin-Rendon E. Meta-analysis of cell therapy trials for patients with heart failure. Circ Res 2015; 116:1361-1377.

40. Guo XI, Li FJ, He YZ, Hou SF, Zhu HB, Cheng Y, et al. Efficacy of Autologous Bone Marrow Mononuclear Cell Transplantation Therapy for Type 2 Diabetes Mellitus: An Updated Meta-Analysis. Diabetes Ther 2019;

41. English K. Mechanisms of mesenchymal stromal cell immunomodulation. Immunol Cell Biol 2013; 91:19-26.

42. Sensebe L., Fleury-Cappellesso S. Biodistribution of mesenchymal stem/ stromal cells in a preclinical setting. Stem Cells Int 2013; 2013:678063-

43. Borgonovo T, Solarewicz MM, Vaz IM, Daga D, Rebelatto CL, Senegaglia $A C$, et al. Emergence of clonal chromosomal alterations during the mesenchymal stromal cell cultivation. Mol Cytogenet 2015; 8:94- 